2 Chiba T, Kasai M, Sasano N. Histopathological studies on intrahepatic bile ducts in the vicinity of the porta hepatis in biliary atresia. Tohoku f Exp Med 1976;118:199-207.

3 Gautier M, Eliot N. Extrahepatic biliary atresia. Morphological study of 98 biliary remnants. Arch Pathol Lab Med 1981;105:397-402.

4 Mowat AP, Psacharopoulos HT, Williams R. Extrahepatic biliary atresia versus neonatal hepatitis. A review of 136 prospectively investigated infants. Arch Dis Child 1978;51:763-70.

5 El Tuni MA, Clarke MB, Barrett JJ, Mowat AP. Ten minute radiopharmaceutical test in biliary atresia. Arch Dis Child 1987;62:180-4.

6 McClement JW, Howard ER, Mowat AP. Results of surgical treatment for extrahepatic biliary atresia in United Kingdom, 1980-82. Br Med f 1985;290:345-7.

7 Houwen RHJ, Zwierstra RP, Severijnen RSUM, et al. Prognosis of extrahepatic biliary atresia. Arch Dis Child 1989;64:214-8.

8 Suruga K, Miyano T, Arai T, Deguchi E. A study on hepatic portoenterostomy for the treatment of atresia of the biliary tract. Surg Gynecol Obstet 1984;159:53-4.

Ohi R, Hanamatsu M, Mochizuki I, Chiba T, Kasai M. Progress in the treatment of biliary atresia. World f Surg 1985;9:285-93.

10 Hala Y, Uchino J, Kasai $M$. Revision of portoenterostomy in congenital biliary atresia. $f$ Pediatr Surg 1985;20:217-20.

11 Canty TG, Self TW, Collins DL, Bonald L. Recent experiences with a modified Sawajuchi procedure for biliary atresia. $\mathcal{F}$ Pediatr Surg 1985;20:211-6.
12 Shin WKT, Jin-She L. Antirefluxing Roux en Y drainage valve for hepatic portoenterostomy: animal experiments and clinical experience. F Pediatr Surg 1985;20:689-92.

13 Reynolds M, Luch SR, Raffensberger JG. The valved conduit prevents ascending cholangitis-a follow-up. F Pediatr Surg 1985;20:696-701.

14 Ecoffey C, Rothman E, Bernard O, Hadchonal $M$, Valayer J, Alagilee D. Bacterial cholangitis after surgery for biliary atresia. $\mathcal{F}$ Pediatr 1987;111:824-9.

15 Starzl TE. Fifteen years of clinical liver transplantation. Gastroenterology 1979;77:375-88

16 Lilly JR, Hall RJ, Altman RP. Liver transplantation and Kasai operation in the first year of life. Therapeutic dilemma in biliary atresia. $\mathcal{F}$ Pediatr $1987 ; 110: 561-2$.

17 Kaufman SS, Murray ND, Wood RP, Shaw BW, Vanderhoof JA. Nutritional support for the infant with extrahepatic biliary atresia. $\mathcal{I}$ Pediatr 1987;110:679-86.

18 Karrer FM, Lilly JR. Corticosteroid therapy in biliary atresia. F Pediatr Surg 1985;20:693-4.

19 Hays DM, Kimura K. Biliary atresia: new concepts of management. Curr Probl Surg 1981;18: 539-608.

20 Watanabe Y, Tadani T, Kabayashi T, Fujii T, Arata A. Glucagon administration for the treatment of postoperative cholangitis after Kasai's operation. $Z$ Kinderchir 1983;38:83-7.

21 Hirsig J, Bircher A, Richham P. Choleretic therapy for biliary atresia patients. Excerpta Medica International Congress Services 1983;627:197.

22 Mieli-Vergani G, Howard ER, Portman B, Mowat AP. Biliary atresia-missed opportunities for effective surgery. Lancet 1989;i:421-3.

\title{
Continuing medical education in general practice
}

\author{
We know who and why but not how good it is
}

Doctors need to keep up to date. In the 1950s and 1960s an acceptance of the need for continuing medical education in general practice led to the development of postgraduate centres to which all doctors had access. Educational meetings at these centres were funded by the National Health Service under section $63 .^{1}$

Since the financial incentive to attend these meetings has been removed several studies have looked at what general practitioners think of postgraduate education ${ }^{2}$ and whether they participate. ${ }^{3} \mathrm{~A}$ recent study from the west midlands, published by the Royal College of General Practitioners, explored in detail the attitudes and behaviour of general practitioners regarding postgraduate education. ${ }^{4}$ A detailed questionnaire was sent to a random sample of general practitioners to assess the difference between attenders and non-attenders at activities under section 63.

The findings supported the work of earlier investigators: nearly three quarters of general practitioners attended one or more lunchtime meetings under section 63 and more than half the non-attenders did not attend any other educational activities. The investigators also examined general practitioners' reading habits. Most scanned newspapers and journals sent to the practices $-89 \%$ read the free weeklies, $73 \%$ the BMF, 27\% the Fournal of the Royal College of General Practitioners, and 5\% the Lancet. The influence of the pharmaceutical industry was important, the industry sponsoring $82 \%$ of the non-section 63 meetings; three out of four general practitioners said that drug companies sponsored all the practice based meetings they had attended.

Practices differed in their commitment to continuing medical education; in some, provisions for study leave were inscribed in practice agreements whereas others actively discouraged leave. Of the general practitioners interviewed, half experienced persistent isolation in their work, and there were strong indications of insecurity and uncertainty. Those who attended postgraduate centres were more mature and resilient to the demands and pressures of practice than nonattenders, who seemed less organised and more conscientious. Non-attenders seemed less extrovert and more isolatedmuch less "clubbable" than attenders (which conflicts with the commonly held view that doctors who do not attend postgraduate centres spend their time on the golf course).

Of the various types of postgraduate education, the formal lecture presentation was preferred. Many general practitioners had reservations about the quality of the meetings they attended: $40 \%$ in one study were critical of the standard of presentation. $^{5} 6$ In contrast, many who attended practice based meetings noted the high calibre of material available on video tapes.

None of these studies have examined the outcome of continuing medical education. In view of the costs to those attending and organising these activities this is surely a topic that requires further research. It has been suggested that in the United States the continuing medical education "industry" does not sufficiently improve performance to justify the current expenditures of effort and money. Sanazaro concluded that continuing medical education is but one link in the "quality assurance chain." There is clear evidence that having the most up to date knowledge (K) and attitudes (A) does not necessarily mean translation into practice $(P)$, the so called "KAP" gap. ${ }^{8}$

General practitioners and hospital staff should, by peer audit, examine their performance and identify the subjects in which further education is required. ${ }^{9-11}$ In consultation with their clinical tutor (which, according to the report, every general practitioner should have) doctors can plan the right educational programme, whether this is clinical attachment to a postgraduate centre, distance learning, or practice based education.

\section{T C O'DOWD Senior Lecturer \\ P D SPRACKLING \\ Regional Advisor in General Practice}

Departments of General Practice and Postgraduate Medicine,

University of Nottingham, Queen's Medical Centre,

Nottingham NG7 2UH

1 Health Services and Public Health Act 1968. Section 63. London: HMSO, 1968.

2 Reedy BLEC. General practitioners and postgraduate education in the northern region. London: Royal College of General Practitioners, 1979. (Occasional paper 9.)

3 Wood J, Byrne PS. Section 63 activities. London: Royal College of General Practitioners, 1980. (Occasional paper 11.)

4 Branthwaite A, Ross A, Henshaw A, Davie C. Continuing education for general practitioners. London: Royal College of General Practitioners, 1988 (Occasional paper 38.)

5 Pickup AJ, Mee LG, Hedley AJ. The general practitioner and continuing education. $f$ R Coll Gen Pract 1983:33:486-90.

6 Pickup AJ, Mee LG, Hedley AJ. Obstacles to continuing education. $7 R$ Coll Gen Pract 1983;33:799-801.

7 Sanazaro PJ. Determining physicians' performance. Evaluation and the Health Professions 1983;6:197-210.

8 Rogers EM. Diffusion of innovations. 3rd ed. New York: Free Press, 1983:69-70.

9 Schofield TPC, Hasler JC. Approval of trainers and training practices in the Oxford Region: criteria. BrMed f 1984;288:538-40.

10 Schofield TPC, Hasler JC. Approval of trainers and training practices in the Oxford Region: assessment. BrMed $\mathcal{F}$ 1984;288:612-14.

11 Schofield TPC, Hasler JC. Approval of trainers and training practices in the Oxford Region: evaluation. BrMed f 1984;288:688-9. 